This item was submitted to Loughborough's Research Repository by the author.

Items in Figshare are protected by copyright, with all rights reserved, unless otherwise indicated.

\title{
Does regulation drive international research cooperation? Evidence from the pharmaceutical sector
}

PLEASE CITE THE PUBLISHED VERSION

https://doi.org/10.1111/twec.12741

PUBLISHER

Wiley

VERSION

AM (Accepted Manuscript)

\section{PUBLISHER STATEMENT}

This is the peer reviewed version of the following article: BENNATO, A.R. and MAGAZZINI, L., 2018. Does regulation drive international research cooperation? Evidence from the pharmaceutical sector. The World Economy, 42(4), pp.1200-1223, which has been published in final form at https://doi.org/10.1111/twec.12741. This article may be used for non-commercial purposes in accordance with Wiley Terms and Conditions for Use of Self-Archived Versions.

\section{LICENCE}

CC BY-NC-ND 4.0

\section{REPOSITORY RECORD}

Bennato, Anna Rita, and Laura Magazzini. 2018. "Does Regulation Drive International Research Cooperation? Evidence from the Pharmaceutical Sector”. figshare. https://hdl.handle.net/2134/35838. 


\title{
Does Regulation drive International Research Cooperation? Evidence from the Pharmaceutical Sector
}

\author{
Anna Rita Bennato ${ }^{\mathrm{a}, \mathrm{b}} \quad$ Laura Magazzini ${ }^{\mathrm{c*}}$

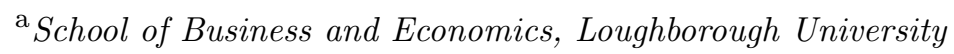 \\ ${ }^{\mathrm{b}}$ Centre for Competition Policy, University of East Anglia \\ ${ }^{\mathrm{c}}$ Department of Economics, University of Verona
}

\begin{abstract}
To what extent is an increased stringency of the Intellectual Property Rights (IPR) system apt to stimulate research cooperation between developed and emerging economies? To address this question, we empirically investigate how international joint research projects in the pharmaceutical sector are affected by the regime of IPR in force in the two countries involved in the collaboration. Looking at the joint signature of both patent documents and scientific articles by researchers located in developed and emerging markets, our investigation indicates two opposite effects: joint publications are fostered by stricter IPR rules, whereas joint patents are discouraged. A recently proposed theory provides a plausible rationale for this apparently contradicting result.
\end{abstract}

Keywords: Intellectual Property Right, R\&D Co-operation, Pre-sample Mean Estimator. JEL classification: O34; O57.

${ }^{*}$ E-mail addresses: a.bennato@lboro.ac.uk (A.R. Bennato), and laura.magazzini@univr.it (L. Magazzini). 


\section{Introduction}

To be successful in the creation of new knowledge substantial research and development (R\&D) investments are needed. The uncertainty associated with the revenues from this type of investments has motivated the introduction of different policy interventions with the objective of strengthening the incentives to innovate. In particular, based on the general idea that sees innovation as the driving force of economic growth, policy makers around the world have set a common strategy to protect Intellectual Property Rights (IPR), which has been defined in the multilateral trade agreement on Trade-Related Aspects of Intellectual Property Rights (TRIPs). Extended to all World Trade Organization (WTO) members, the new rules impose a minimum standard in the protection and enforcement of the IPR, with the purpose of encouraging cooperation among countries (WTO, 2016).

In this paper we examine the role played by IPR protection in research cooperation between developed and emerging market economies, by exploiting the latest change in the intellectual property regulation introduced within the TRIPs agenda. Established in 1995 in all developed economies, this radical reform provides a unique opportunity to evaluate the effects of a change in the stringency of IPR protection on cooperative research projects. Interestingly, the change in the intellectual property regime was ratified differently across countries. Contrary to developed economies, developing countries were granted a longer transition period up to 2000, with an additional extension until 1 January 2005 for the protection in technological areas that had not been protected before the TRIPS Agreement 11 The pharmaceutical sector is one such area, and it represents the focus of our research, which assesses the effects of the new intellectual property law on joint research projects between developed and emerging market economies.

We adopt a dual approach to test whether a sharper set of institutions designed to protect the IPR was able to spur international research collaborations in the pharmaceutical domain. Specifically, we examine the dynamics that characterize collaborations both in science and technology measured by the number of publications and the number of patents jointly signed by researchers located in developed and emerging market economies. Focusing on both patents and publications, our proposed method of analysis gives us the opportunity to explore in detail the use of open science, which is commonly adopted to disclose knowledge in industrial sectors where the IPR protection is quite strong, as in the pharmaceutical domain (Cockburn and Henderson, 1998).

To disentangle the role of the change in IPR regime, our empirical analysis relies on a grav-ity model approach. The distribution of knowledge and expertise across countries is determined by gravity forces which in our model are dependent on the size of scientific and technological capabilities of each country. Hence, given its tractability and parsimonious representation of countries economic interactions, a gravity model provides us with a suitable approach to study the impact of the new set of IPR regulations on research collaborations at the international level. We concentrate on the pharmaceutical sector as the leading example of a science-based sector, which widely relies on IPR to capture returns from R\&D investments (see Cohen, Nelson and Walsh, 2000; DiMasi, Grabowski and Vernon, 2004; Henderson and Cockburn, 1996). To

\footnotetext{
${ }^{1}$ As an example, Brazil, India and Turkey employed the full transition period, before granting product patents on pharmaceuticals in 2005 (Hamdan-Livramento, 2009).
} 
secure $R \& D$ revenues this industry has historically made use of a variety of instruments other than IPR protection (i.e. secrecy, licensing agreements, etc.). However, when a tighter intellectual property system was adopted, the number of new drugs launched increased (see Cockburn, Lanjouw and Schankerman, 2016; Kyle and McGahan, 2012), underlying the pivotal role played by the intellectual property protection for this sector (Cohen, Nelson and Walsh, 2000). Moreover, since the drug development process depends heavily on the advances in different related scientific areas, cooperative research agreements have been widely employed as an institutional mechanism to avoid duplication of costs (among others see Katsoutacos and Ulph, 1998; Katz, 1986; Lin and Zhou, 2013).

The presence of a formal system of IPR rules has proved to be an important source of incentives to new R\&D investments, generating positive effects on a country's economic growth (Falvey, Foster and Greenaway, 2006; Liu, 2016). For higher-income countries, a tighter IPR regime safeguards the returns on $R \& D$ investments, ensuring a more stable monopoly status; for lower-income countries, instead, the presence of a clear set of rules provides a safe environment able to attract new foreign investments. The literature on the impact of IPR reforms on industrial development suggests that firms tend to deploy more technology in those countries where a tougher system of IPR protection is in place (Branstetter, Fisman, Foley and Saggi, 2011). An ambiguous intellectual property system, indeed, discourages R\&D co-investment between rivals (Czarnitzki, Hussinger and Schneider, 2015), whereas stronger regimes of intellectual property rights facilitate technology transfer (Kanwar, 2012). Evaluating the effects of the TRIPs agreement on new medical treatments, Kyle and McGahan (2012) confirm the prediction that a clear system of IPR yields an increase of R\&D investments in developed economies. On the other hand, Qian (2007) shows that the enactment of a stricter patent law by itself does not foster R\&D expenditures and innovation in the pharmaceutical sector, since other characteristics such as the level of education and the degree of economic freedom turn out to be more crucial.

In the scientific domain, although joint co-authorships are motivated by different goals (Cockburn and Henderson, 2000), a clear system of rules able to protect intellectual property is considered of a great importance. Academic articles often report results about important advancements for specific projects that are developed jointly with different researchers and institutions. In the presence of an imperfect mechanism of intellectual property appropriability, scientists may be refrained from developing collaborations with their peers located in countries unable to guarantee a secure environment to protect their own IPRs (Gans, Murray and Stern, 2017). Although patents and other forms of intellectual property protection fortifies incentives to un-dertake risky research projects, their own existence may jeopardize their advancement in science when a plurality of right holders owns a specific discovery, with consequences on the diffusion and utilization of scientific knowledge (Heller and Eisenberg, 1998).

Our paper contributes to the long-standing debate on the role of intellectual property in international cooperative research along three dimensions. First, we separately analyse and compare the two different domains in which research cooperation takes place, that is technological and scientific innovation. Second, to capture as broadly as possible the actual degree of the new IPR system in a country we make use of two complementary measures that quantify respectively the objective and the subjective level of such a protection. Third, we adopt a novel empirical 
strategy based on a gravity framework where the attraction force of each country is represented by the existing stock of technological and scientific knowledge. Our results indicate that a more rigorous system of IPR protection has yielded two distinct outcomes. On the one hand, we uncover a negative impact on technological collaborations between developed and emerging market economies, despite a simultaneous considerable rise in the number of new patent applications at the international level2 2 On the other hand, we find that scientific collaborations have significantly benefitted from the new IPR rules, providing new evidence of the actual impact of the legal protection on the output of scientific research (see Heller and Eisenberg, 1998; Lach and Schankerman, 2008; Murray and Stern, 2007). These two apparently contradicting findings are consistent with the theory that highlights how the disclosure of unknown information to the public domain may be used strategically to curb competitors patent applications (Baker and Mezzetti, 2005; Ponce, 2008). Our conclusions are robust to alternative model specifications and definitions of the explanatory variables. Moreover, to corroborate our results, we present a placebo estimation in a sector where IPR protection is expected to be neutral.

The structure of the paper is the following. Data and measures are described in the next Section. Details on the adopted methodology and our empirical strategy are explained in Section 3. Results and robustness checks are reported in Section 4 and Section 5, respectively, whereas Section 6 concludes.

\section{Data and measures}

We collected annual data from publicly available databases for a panel of $17 \times 7$ country pairs, including 17 developed economies (i.e. Canada, Japan, Switzerland, USA, and 13 European countries) 3 and 7 emerging market economies (i.e. Brazil, China, India, Mexico, Russia, South Korea, and Turkey) 4 As our goal is to empirically assess the effects of the change in the strength of IPR protection on international research cooperation, our dependent variable captures alternatively technological and scientific collaborations between developed and emerging economies, measured by the number of joint patents and joint publications. Our variables are constructed employing ad hoc queries on FreePatentsOnline search engine for inventions (patents) related to pharmaceuticals, and from ISI Web of Knowledge for the peer-reviewed research articles published about health-related subjects 5 Information on patents and scientific publications has been obtained over the period 1978-2011.

\footnotetext{
${ }^{2}$ See for details, http://www.wipo.int/publications/en/details.jsp?id=4138

${ }^{3}$ For the European countries, we consider EU 15 which includes Austria, Belgium, Denmark, Finland, France, Germany, Greece, Ireland, Italy, Luxembourg, the Netherlands, Portugal, Spain, Sweden and the United Kingdom, where the Benelux (Belgium, the Netherlands and Luxembourg) has been considered as a unique entity.

${ }^{4}$ The selected developing countries were originally identified by a leading consultant firm in the health care industry as the emerging pharmaceutical markets (IMS Health; see http://www.imshealth.com). These countries are included among the developing countries by the World Bank with the exception of South Korea, which is listed as high-income country since 1997 (details on http://data.worldbank.org/about/country- classifications/countryand-lending-groups).

${ }^{5}$ The FreePatentsOnline search service enables full-text search of published international patent applications from 1978 (more details on http://www.freepatentsonline.com), whereas for ISI Web of Knowledge information has been extracted from Web of Science database (see http://apps.isiknowledge.com). Since journals publish scholarly material in a different variety of matters, we confine our data to research articles that are defined by their health-related contents. Particularly, we consider articles containing the following terms: pharma OR biotech OR drug OR therapeutic OR disease OR medical.
} 

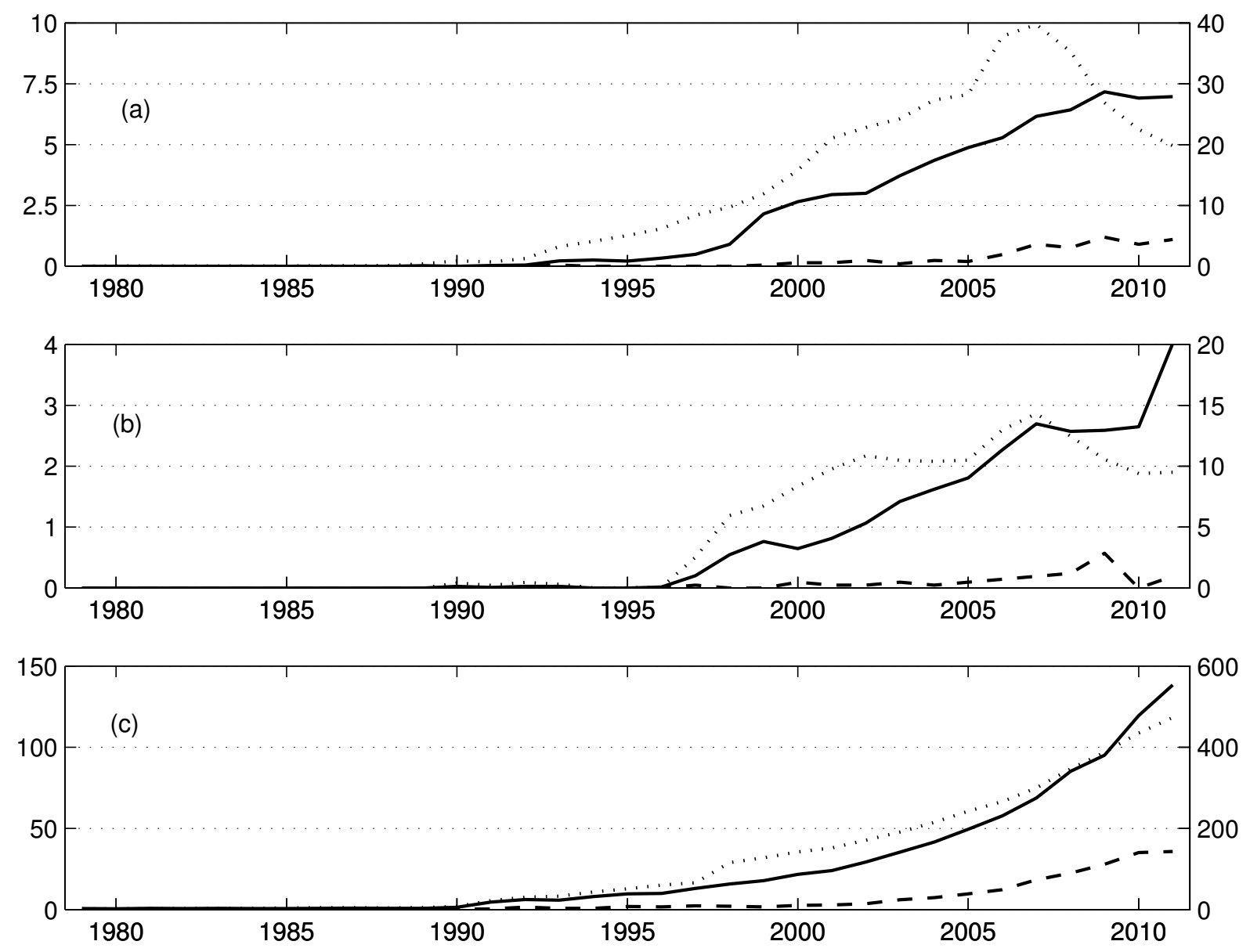

Figure 1: International R\&D collaboration in (a) patents, with count based on applicants' location; (b) patents, with count based on inventors' location; and (c) publications. Sample average between (i) developed economies - dotted line, right axes; (ii) emerging market economies - dashed line, left axes; and (iii) developed economies and emerging market economies - solid line, left axes.

In order to identify pharmaceutical patents, we consider the two International Patent Classification (IPC) classes A61K and A61P6 An international technological collaboration is counted if a patent is jointly signed by two (or more) applicants (those who hold full rights to the innovation) located in two different countries. As a complementary measure, we also count international technological collaborations on the basis of the geographical location of the inventors (those who have conceived a particular innovation). Results obtained with the two measures are broadly consistent. Due to the scope of our analysis, we use international patents, which refer to the applications submitted to the World Intellectual Property Organization (WIPO), i.e. patents granted under the Paris Convention Treaty (PCT), as this system is designed to potentially protect innovations both in developed and emerging countries.

As we are interested in the dynamics of total research output in the pharmaceutical sector, we consider all active researchers in both academia and industry. Determination of their location is

\footnotetext{
${ }^{6}$ The class A61K includes "preparations for medical, dental, or toilet purposes", whereas the class A61P considers the "therapeutic activity of chemical compounds or medicinal preparations". For further details see: http://www.wipo.int/classifications/ipc/en/.
} 
made possible by the fact that the Web of Science database reports the affiliation of all authors listed in a publication, including their full address. Thus, a scientific collaboration between two countries is considered if the publication is jointly signed by researchers located in these countries. In the recent years, co-ownerships both in science and technology have shown a positive trend at the international level (Ductor, 2015).

Table 1: IP related data for emerging market economies

\begin{tabular}{|c|c|c|c|}
\hline Country & $\begin{array}{ll}\text { Entry into } \\
W T O\end{array}$ & $\begin{array}{l}\text { Patent law in- } \\
\text { troduction }\end{array}$ & $\begin{array}{l}\text { End of transition } \\
\text { pe-riod for pharma }\end{array}$ \\
\hline Brazil China & 1995 & 1997 & 2005 \\
\hline India Mexico & 2001 & 1993 & 2001 \\
\hline Russia South & 1995 & 2003 & 2005 \\
\hline Korea & 1995 & 1991 & 2000 \\
\hline \multirow[t]{3}{*}{ Turkey } & 2012 & 2008 & 2012 \\
\hline & 1995 & 1997 & 2000 \\
\hline & 1995 & 1999 & 2005 \\
\hline
\end{tabular}

Note: Data about WTO memberships have been retrieved from
https://www.wto.org/english/thewto_e/whatis_e/tif_e/org6_e.htm.
introduction of the patent law in our emerging market economies: Brazil see Schulz and
Wu (2004); China see Chengsi (1998); India see IPO
Leung (2017); Mexico see Sandoval and
Turkey see Suluk
are retrieved from Kyle and Qian (2018).

In order to explore the pattern of collaborative research in our sample of countries, Figure 1 plots the average number of collaborations per year, measured on the basis of patents, both applicants (panel a) and inventors (panel b), and on the basis of scientific publications (panel c), distinguishing whether these involve (i) developed economies, (ii) emerging market economies, or (iii) both. The reference year is the application (filing) date for patents and the publication date for scientific articles. We observe that patents involving a collaboration between developed and emerging market economies have increased quite steadily since 1995, but with different dynamics. In the case of patents, a downward trend is observed since 2006. The decrease in the number of patents in the last four years can be partially explained by the time lag between the filing and the publication (acceptance) date. The dynamics of publications is characterized by a constant growth rate across all three groups of countries. Among the emerging economies, China has always the highest number of international collaborations, followed by India for patents and Brazil for scientific publications. It is interesting to note that, despite in some cases a patent law already being in place, the majority of the emerging economies in our sample have opted for the use of the entire transition period for the pharmaceutical sector, updating their IP system years after the signature of the TRIPS agreement. Details are reported in Table 1, which lists for each emerging market economy in our sample the date of entry into the WTO, the introduction for the first time of a general patent law, and the end of the transition period for pharmaceuticals, respectively.

To gauge the degree of IPR protection in each country two complementary indices are con- 
sidered. First, we employ the broadly used Ginarte-Park index, which rates the intellectual property (IP) protection and enforcement compliance for each country by aggregating five separate scores on the degree of coverage. Several objective criteria are adopted by this index to capture the strength of protection that a nation is able to provide, including membership to international treaties, duration of protection, enforcement mechanisms, and restrictions (Ginarte and Park, 1997; Park, 2008). Taking into account the length of protection, the mechanisms for enforcing patent rights, and the evolution of the international patent laws, the Ginarte-Park index measures the overall strength of the legal structure and security of the IPR system. Allowing for difference in effective protection across countries, the Ginarte-Park index varies from zero to five with higher values of the index indicating stronger protection. The index is available at five-year intervals over a long time span (1960 up to 2005).

As an additional dimension of the strength of IPR, we adopt a measure based on the Executive Opinion Survey provided by the World Economic Forum (Gwartney, Lawson and Norton, 2008), henceforth referred to as EOS. We have drawn information on the index value over the years 2000-2009,7 and one point value is also available for the year 1995. This index captures the subjective assessment of the IPR level expressed by executives of (mainly large) firms located in the dominant sectors of the economy. The positive low correlation between the two indices (about 0.45 and 0.30 for respectively developed and emerging market economies) mirrors the difference between the actual legal protection and the perceived level of protection for IPR among practitioners (Gwartney, Lawson and Norton, 2008). In Table 2 we report basic statistics of the two indices based on our sample, decomposing the total variance in the between and within components 8

Table 2: Objective and subjective measures of the strength of the protection of IPR

\begin{tabular}{lcccc}
\hline \hline & \multicolumn{2}{c}{ Ginarte-Park } & \multicolumn{2}{c}{ EOS } \\
\cline { 2 - 5 } & $\begin{array}{c}\text { Emerging } \\
\text { markets }\end{array}$ & $\begin{array}{c}\text { Developed } \\
\text { economies }\end{array}$ & $\begin{array}{c}\text { Emerging } \\
\text { markets }\end{array}$ & $\begin{array}{c}\text { Developed } \\
\text { economies }\end{array}$ \\
\hline \multirow{2}{*}{ Mean } & 3.322 & 4.445 & 4.048 & 7.467 \\
Total variability & 0.878 & 0.283 & 1.091 & 1.184 \\
Between variability & 0.560 & 0.231 & 0.991 & 1.088 \\
Within variability & 0.699 & 0.171 & 0.580 & 0.529 \\
\hline Growth 1995-2000 & 0.505 & 0.058 & -0.029 & 0.157 \\
Growth 2000-2005 & 0.154 & 0.012 & 0.195 & -0.024 \\
\hline
\end{tabular}

As expected both indices are higher in developed economies than in emerging market economies.

\footnotetext{
${ }^{7}$ In order to enhance comparability among the two indices, in the analysis we only use information on the Ginarte-Park index for the years 2000 and 2005.

${ }^{8}$ Let $\pi_{i t}$ be the measure of patent protection for country $i$ at time $t$. The total variability is computed as the square root of $\sum_{i=1}^{N} \sum_{t=1}^{T}\left(\pi_{i t}-\bar{\pi}\right)^{2} /(N T)$ with $\bar{\pi}$ being the overall average of $\pi_{i t}$. With $\bar{\pi}_{i}$ identifying the average over time of the observations on country $i$, between variability captures variability across countries, more precisely it is defined as the square root of $\sum_{i=1}^{N}\left(\bar{\pi}_{i}-\bar{\pi}\right)^{2} / N$. Finally, within variability amounts to the square root of $\sum_{i=1}^{N} \sum_{t=1}^{T}\left(\pi_{i t}-\bar{\pi}_{i}\right)^{2} /(N T)$, capturing the variation over time of the index at the country level.
} 
However, the two indices exhibit quite different dynamics in terms of average growth rate. The value of within and between variability reveals that our sample of countries differs in terms of the level of IPR protection, and changes have occurred within countries in the analysed time frame. Over the period 1995-2005, the Ginarte-Park index has remained fairly stable for devel-oped countries, whereas it has increased considerably for emerging economies. As developing economies were given up to 2005 to comply with the new IPR regulations, the different dynamics are most likely due to the extensive normative changes that occurred in the IPR system for this latter group of countries. On the contrary, a change in trend is observed for EOS index over the two time periods for both groups of countries. For developed economies, a growth in the perceived IPR protection is observed over the period 1995-2000, whereas for emerging countries the EOS index increases at a later stage. More likely this effect is due to the time lag needed for emerging economies to update their legal system (see among others Maskus and Penubarti, 2012). The negative sign in the growth for both set of countries, at different stages, reflects a decrease in trust in the protection of their own IPRs. In the next Section we show how the difference between the perceived and the observed IPR protection is decisive for our results.

\section{Empirical approach: a gravity model of R\&D cooperation}

Our analysis is based on the use of a standard gravity model, which has been successfully employed to study the determinants of international flows between nations, as defined by specific economic forces of either the origin or the destination country (Anderson and Van Wincoop, 2003). More specifically, based on the Newton's law of universal gravitation, a standard gravity model explains the behavior of bilateral flows between two countries as proportional to their masses and inversely proportional to the distance between them.

In our gravity equation, besides masses, we include the two measures of the strength of IPR protection to investigate whether the increased stringency of IPR protection in the emerging market economies has attracted collaborative research partnerships with the developed world in the pharmaceutical sector.

Indicating by $C_{i j t}$ the number of (technological or scientific) collaborations between country $i$ (developed) and country $j$ (emerging) at time $t$ (year), our gravity equation is specified as follows:

$$
E\left[C_{i j t} \mid X_{i j t}, \alpha_{i j}\right]=\exp \left(X_{i j t}^{\prime} \beta+\tau_{t}+\alpha_{i j}\right)
$$

where

$$
X_{i j t}^{\prime} \beta=\beta_{0}+\beta_{1} \ln M_{i t-1}+\beta_{2} \ln M_{j t-1}+\beta_{3} \ln I P R_{i t}+\beta_{4} \ln I P R_{j t}
$$

with $M_{i t-1}$ and $M_{j t-1}$ the masses of, respectively, country $i$ and $j$ at time $t-1,9$ and $I P R_{k t}$ measuring the IPR protection in country, $k$ for $k=i, j$ at time $t 10$ Following the Schumpeterian

\footnotetext{
${ }^{9}$ One-year lag is considered in order to avoid endogeneity, as masses at time $t$ also include cooperation at time $t$. Moreover, for countries with zero patents and publications we add a one to the masses $M_{k t}(k=i, j)$ when calculating the logarithm.

${ }^{10}$ Note that our dependent variable measures bilateral collaborations between two countries. Country pairs are counted only once. All explanatory variables are expressed in logarithms, and two separate models are considered in which $I P R$ is measured using the Ginarte-Park index and the EOS index. Concerns may arise about the endogeneity of the two IPR indices, as the level of IPR protection has been historically chosen by countries fostered by domestic innovators or when achieving a rather high level of development (Qian, 2007). However, in
} 
tradition, the masses $M_{k t}$ are measured alternatively by the total number of patents or publications in the pharmaceutical domain to gauge the stock of technological and scientific capabilities at the country level (Griliches, 1990). Thus, the dynamics of the stock knowledge is defined as

$$
M_{k t}=P_{k t}+(1-\delta) M_{k t-1},
$$

with $P_{k t}$ representing the new technological or scientific flow (respectively, the number of patents or publications) of country $k$ at time $t(k=i, j)$, where we set $\delta=13.11 \%$, identified as the industry-specific estimated depreciation rate estimated by Park and Park (2006). Because the distance between our two countries is time invariant, it will be modeled as a fixed effect. Hence, a dyad fixed effect $\alpha_{i j}$ is included in the equation to control for all observable and unobservable dyad-specific characteristics that are invariant over time, e.g. the distance between country $i$ and $j$. Besides distance, gravity regressions usually include a set of controls such as the existence of colonial links, use of a common language (e.g. Picci, 2010) that are effectively accounted for by the presence of $\alpha_{i j} 11$ Time dummies $\left(\tau_{t}\right)$ are included in all specifications to account for time-specific effects affecting all collaborations. Descriptive statistics of the variables included in these baseline regressions are reported in Table 3.

In order to estimate the parameters of a standard gravity equation, the model (3)] is customarily log-linearized and ordinary least squares is applied. This approach, however, has been recently criticized, as the use of the log-linear form of the gravity equation may produce inconsistent estimates of the model elasticities when heteroschedasticity is present in the original equation (Silva and Tenreyro, 2006, 2011). Hence, we follow Silva and Tenreyro (2006, 2011) and apply the Poisson analytical approach to study the effect of the change in the strength of the IPR system on technological and scientific research cooperations. The Poisson regression framework also allows researchers to deal with the possibility of zero flows between two coun-tries, which could be common in the current framework, and in our sample (Silva and Tenreyro, 2011). In order to estimate the model parameters, we exploit the availability of pre-sample infor-mation on the dependent variable and employ the pre-sample mean estimator (PME) proposed by Blundell, Griffith and Van Reenen (1995) and Blundell, Griffith and Windmeijer (2002). This estimator has the virtue of allowing both correlation between the fixed effects $\alpha_{i j}$ and the variables included in the regression, as well as the presence of predetermined variables in the equation (see Windmeijer, 2008). Allowing for feedback effects is quite important in our con-text, because the collaboration at time $t$ between two countries likely produces beneficial effects on the production of knowledge (and therefore on the masses) of both countries in subsequent years. The estimator has also been shown to perform well in small samples and in the case of persistent variables (Blundell, Griffith and Windmeijer, 2002). Consistent estimates of the model parameters in equation [3) are obtained by using the pre-sample average of the dependent

the case of TRIPS, Kyle and McGahan (2012) argue that developing and least developed countries did strengthen the level of IPR protection only because they expected large benefits from the membership in the WTO (see also Shin, Lee and Park, 2016). Hamdan-Livramento (2009) also examines the TRIPS agreement and concludes that the implementation of the IP reform is an external factor which is not completely dependent on the level of economic development.

${ }^{11}$ In Section 5 we present a set of robustness checks where additional control variables have been employed. 
Table 3: Descriptive statistics of the variables included in the regressions

\begin{tabular}{|c|c|c|c|c|}
\hline Variable & Mean & Std. Dev. & Min & $\operatorname{Max}$ \\
\hline \multicolumn{5}{|c|}{ Patents (assignees) } \\
\hline$C_{i j}$ & 5.037 & 19.306 & 0.000 & 173 \\
\hline $\ln M_{i}$ & 7.089 & 2.174 & 0.965 & 10.925 \\
\hline $\ln M_{j}$ & 5.250 & 2.455 & 0.000 & 9.253 \\
\hline \multicolumn{5}{|c|}{ Patents (inventors) } \\
\hline$C_{i j}$ & 2.098 & 9.130 & 0.000 & 184 \\
\hline $\ln M_{i}$ & 7.015 & 1.768 & 1.996 & 10.847 \\
\hline $\ln M_{j}$ & 5.574 & 1.516 & 1.747 & 7.964 \\
\hline \multicolumn{5}{|c|}{ Publications } \\
\hline$C_{i j}$ & 63.792 & 171.886 & 0.000 & 3199 \\
\hline $\ln M_{i}$ & 10.083 & 1.212 & 6.916 & 13.043 \\
\hline $\ln M_{j}$ & 9.156 & 0.713 & 7.819 & 11.959 \\
\hline \multicolumn{5}{|c|}{ Protection of IPR } \\
\hline $\ln E O S_{i}$ & 2.007 & 0.173 & 1.482 & 2.241 \\
\hline $\ln E O S_{j}$ & 1.363 & 0.276 & 0.642 & 1.988 \\
\hline $\ln G P_{i}$ & 1.510 & 0.044 & 1.379 & 1.585 \\
\hline $\ln G P_{j}$ & 1.297 & 0.155 & 0.819 & 1.466 \\
\hline
\end{tabular}

Note: $C_{i j}, M_{i}$ and $M_{j}$ are the sample means of the corresponding variables in equation (3). $E O S_{k}$, and $G P_{k}$ with $k=i, j$ are the sample means of the EOS and Ginarte-Park indices, respectively.

variable as a proxy for the fixed effect $\alpha_{i j}$. The estimated model is therefore defined as

$$
C_{i j t}=\exp \left(X_{i j t}^{\prime} \beta+\tau_{t}+\gamma \ln \bar{C}_{i j P}\right)+\epsilon_{i j t}
$$

with $\bar{C}_{i j P}=1 / P \sum_{s=0}^{P-1} C_{i j 0_{-s}}$ being the pre-sample mean of the dependent variable and $\gamma$ is a parameter to be estimated 12 Standard errors are estimated using the methodology proposed by Cameron, Gelbach and Miller (2011) that allows cluster-robust inference in the case of nonnested two-way clustering 13

In the light of the data reported in Figure 1, avoiding problems arising from the applicationgrant lag, for patents the estimation period spans the period 2000-2008, whereas for publications we consider the full time frame from 2000 to 2009.

\footnotetext{
${ }^{12}$ In order to avoid removing observations with zero pre-sample mean $\bar{C}_{i j P}$, we added one to the pre-sample counts of collaborations. Given the observed dynamics in the evolution of the dependent variables, the pre-sample average is computed over the time period 1995-1998.

${ }^{13}$ In our analysis, it is not possible to assume independence among the dyads. As an example, dyad $i j$ is correlated with dyad $i k$ even if $j \neq k$, due to the presence of country $i$ in both dyads.
} 


\section{Estimation results}

The results of our estimation for both technological and scientific collaborations within the health-related framework are displayed in Table 4. The Table is organized as follows. In the first four columns after the description of our regressors, we report the estimates for the bilateral technological research cooperation measured by the number of joint patents, considering the location of both the applicants (second and third columns) and the inventors (fourth and fifth columns). In the last two columns, instead, we present the estimates for the scientific research cooperation between two countries, measured by the number of joint international publications (sixth and seventh columns). The coefficients on the masses $M_{i t}$ and $M_{j t}$ are significant and have the expected positive sign, indicating that the larger is the knowledge base of the two countries the stronger is their "attraction force" with respect to research collaborations.

Table 4: Main estimation results of our baseline gravity model

\begin{tabular}{lllllll}
\hline \hline \multirow{2}{*}{ IPR measure } & \multicolumn{2}{c}{$\begin{array}{c}\text { Patents } \\
\text { (applicants) }\end{array}$} & \multicolumn{2}{c}{$\begin{array}{c}\text { Patents } \\
\text { (inventors) }\end{array}$} \\
\cline { 2 - 7 } & $G-P$ & $E O S$ & $G-P$ & $E O S$ & $G-P$ & EOS \\
\hline \hline $\ln M_{i t-1}$ & $0.767^{* * *}$ & 0.149 & $1.224^{* * *}$ & $1.022^{* * *}$ & $0.203^{* * *}$ & $0.206^{* * *}$ \\
& $(0.169)$ & $(0.191)$ & $(0.149)$ & $(0.208)$ & $(0.047)$ & $(0.033)$ \\
$\ln M_{j t-1}$ & $1.049^{* * *}$ & $1.025^{* * *}$ & $0.915^{* * *}$ & $0.807^{* * *}$ & $0.613^{* * *}$ & $0.643^{* * *}$ \\
& $(0.253)$ & $(0.261)$ & $(0.062)$ & $(0.084)$ & $(0.181)$ & $(0.180)$ \\
$\ln I P R_{i t}$ & $-29.042^{* *}$ & $1.881^{*}$ & 6.729 & $0.844^{* *}$ & $-2.466^{* * *}$ & -0.232 \\
& $(11.296)$ & $(0.994)$ & $(5.140)$ & $(0.342)$ & $(0.934)$ & $(0.270)$ \\
$\ln I P R_{j t}$ & $-4.085^{* * *}$ & -0.3883 & $-1.943^{* * *}$ & -0.4755 & $1.226^{* * *}$ & $0.4642^{* * *}$ \\
& $(0.761)$ & $(0.790)$ & $(0.331)$ & $(0.486)$ & $(0.250)$ & $(0.147)$ \\
$\bar{C}_{i j P}$ & $1.634^{* * *}$ & $1.329^{* * *}$ & -0.074 & 0.296 & $0.975^{* * *}$ & $0.876^{* * *}$ \\
& $(0.390)$ & $(0.313)$ & $(0.389)$ & $(0.297)$ & $(0.046)$ & $(0.075)$ \\
Constant & $37.069^{* * *}$ & $-9.686^{* * *}$ & $-21.731^{* * *}$ & $-12.876^{* * *}$ & $-4.424^{* * *}$ & $-6.785^{* * *}$ \\
& $(15.368)$ & $(2.569)$ & $(8.140)$ & $(1.620)$ & $(0.545)$ & $(0.936)$ \\
& & & & & & \\
N. obs. & 238 & 1071 & 238 & 1071 & 238 & 1190 \\
\hline
\end{tabular}

Note: Standard errors are reported in parenthesis. Statistical significance at ${ }^{* * *} 1 \%,{ }^{* *} 5 \%,{ }^{*}$ $10 \%$.

Considering the level of IPR protection in the emerging market (country $j$ ), we find that its effect on joint publications is positive and significant, using either of the two indices (see the last two columns). As for technological collaborations (joint patents), we always find a negative impact of the IPR index in emerging markets, but this is statistically significant only when using the G-P measure. This difference in significance clearly reflects the two inherently different approaches used to construct the two indices, the observed versus the perceived protection of 
the intellectual property rights 14

When we analyse the IPR level in the developed country (country $i$ ), we find that this has a negative impact on scientific collaborations, using either of the two indices, but again this emerges as significant only using the G-P measure (sixth column). The effect on the number of joint patents, instead, is always positive except in one case, and with ambiguous significance 15

To what extent are these estimated signs sensible, or at least can we provide an intuitive interpretation for this strong evidence of opposing effects on the two types of research collaboration? Since developed countries are characterized by more advanced and effective legal institutions, which ensure a higher and more certain standard of protection (see Table 3), it is very likely that the level of IPR protection in the emerging markets plays a more determinant role, influencing research collaborations between countries. Thus, focusing on this latter, we believe that the estimated opposite sign in the effect on patents and publications can be interpreted in light of the recent theoretical models underlying the dual nature of scientific knowledge. Following the "Pasteur's Quadrant" terminology (for example Stokes, 1997), it is believed that the distinction between basic and applied research tends to vanish in the long run and an increasing number of joint research projects are undertaken with the simultaneous goals of creating a product that has a commercial value (patents), and broadening the scientific knowledge (publications) (Gans, Murray and Stern, 2017). This is particularly relevant in a dynamic setting where innovations are both sequential and cumulative, for which the use of upstream patent is less desirable because it may inhibit future innovations (Bessen and Maskin, 2009; Merges and Nelson, 1990; Scotchmer, 1991). Our results seem to suggest that when the legal background is secured by the introduction of clear rules, the use of patents in pharmaceuticals is likely to be postponed to later stages in order to favor further efforts in the research process that is triggered by the initial idea (Heller and Eisenberg, 1998). As the realization of research projects is increasingly undertaken in more complex organizations, where researchers necessarily interact with different economic agents (i.e. governments, private firms and universities), the conditions under which knowledge is disseminated can follow less traditional patterns (Gans, Murray and Stern, 2017).

From another perspective, it is not uncommon for firms to act tactically by disclosing information on an invention in the form of a defensive publication. This strategy allows firms to create prior art that might stop other competitors from patenting by building up further barriers that jeopardizes rivals' patent application (Baker and Mezzetti, 2005). We stress that not only is there no evidence of a positive impact of strenghtening IPR on the number of collaborative patents, but this relationship, if anything, appears to be negative. While this seems surprising at a first glance, it can easily find justification in the fact that the presence of a clear system of rules on IPR makes unnecessary the recourse to a patent to protect an idea in its early stages. Since the disclosure of new ideas depends on a complex and interacting set of institutions, once a minimum set of rules has been defined, economic agents have more incentives to cooperate at the international level. A further confirmation of this interpretation can be derived by observing

\footnotetext{
${ }^{14}$ As the WTO membership of a country might influence the expectations on the actual IPR protection, we have re-run the estimations removing those observations for Russia and China. As reported in Table 1, China become a WTO member in December 2001, and Russian Federation is a WTO member since August 2012. Results are qualitative the same.

${ }^{15}$ We are interested mainly on the sign and the significance of the effects of the IPR protection, given that the exact magnitude of the coefficients depends on the specific index adopted.
} 
in Table 4 that a significant negative coefficient is only obtained using the objective measure of IPR protection, which captures the strength of the actual legal system in force, and not using the alternative subjective index.

\section{Robustness analysis}

In this Section a set of robustness checks is proposed which aims at exploring the sensitivity of our results to different model specifications. First, we consider different definitions of masses to control for the dynamics of knowledge accumulation. Second, in order to check for alternative potential explanations of the observed pattern in patents and publications, we include additional control variables to our baseline specification, and in particular we assess the statistical relevance of a complete series of potentially important variables. Third, as research projects in the pharmaceutical sector may take several years, we experiment with various lags the IPR protection indices considered in the analysis. Finally, we run a set of "placebo" regressions for the case of scientific collaborations in the field of Economics, building on the idea that a tighter intellectual property system should not affect research collaborations in fields where patenting is not involved.

Table 5: Estimation results using a different definition of mass

\begin{tabular}{|c|c|c|c|}
\hline & $\begin{array}{c}\text { Patents } \\
\text { (applicants) }\end{array}$ & $\begin{array}{c}\text { Patents } \\
\text { (inventors) }\end{array}$ & Publications \\
\hline IPR measure & $G-P$ & $G-P$ & $G-P$ \\
\hline $\ln \tilde{M}_{i t-1}$ & $\begin{array}{l}0.639^{* * *} \\
(0.180)\end{array}$ & $\begin{array}{l}1.191^{* * *} \\
(0.152)\end{array}$ & $\begin{array}{l}0.242^{* * *} \\
(0.055)\end{array}$ \\
\hline $\ln \tilde{M}_{j t-1}$ & $\begin{array}{l}0.899^{* * *} \\
(0.377)\end{array}$ & $\begin{array}{c}0.967^{* *} \\
(0.055)\end{array}$ & $\begin{array}{l}0.755^{* * *} \\
(0.160)\end{array}$ \\
\hline $\ln I P R_{i t}$ & $\begin{array}{l}-29.115^{* * *} \\
(9.516)\end{array}$ & $\begin{array}{l}5.988 \\
(5.187)\end{array}$ & $\begin{array}{l}-2.679^{* * *} \\
(0.813)\end{array}$ \\
\hline $\ln I P R_{j t}$ & $\begin{array}{l}-4.266^{* * *} \\
(1.003)\end{array}$ & $\begin{array}{l}-2.077^{* * *} \\
(0.408)\end{array}$ & $\begin{array}{l}1.209^{* * *} \\
(0.291)\end{array}$ \\
\hline $\bar{C}_{i j P}$ & $\begin{array}{l}1.738^{* * *} \\
(0.353)\end{array}$ & $\begin{array}{l}-0.065 \\
(0.381)\end{array}$ & $\begin{array}{l}0.935^{* * *} \\
(0.025)\end{array}$ \\
\hline Constant & $\begin{array}{l}39.160^{* * *} \\
(13.821)\end{array}$ & $\begin{array}{l}-20.398^{* *} \\
(8.015)\end{array}$ & $\begin{array}{l}-5.560^{* * *} \\
(0.420)\end{array}$ \\
\hline N. obs. & 238 & 238 & 238 \\
\hline
\end{tabular}

Note: Statistical significance at ${ }^{* * *} 1 \%,{ }^{* *} 5 \%,{ }^{*} 10 \%$. 


\subsection{Different definition of mass}

In the baseline regression, an industry-specific constant depreciation rate of $13.11 \%$ was considered for computing the stock of knowledge as defined in equation (2). Because the level of IPR protection can influence the dynamics of knowledge accumulation, in particular its rate of obsolescence, we set a depreciation rate that is inversely related to the country's IPR index when computing the stock of knowledge as in equation (2), letting countries with higher IPR have a lower depreciation rate, and, conversely, countries with lower IPR to have a higher depreciation rate. To assess the level of IPR stringency at the country level, we use historical data on IPR protection, provided by Park (2008). More specifically, letting $\pi_{t}$ be the historical index at time $t$, the constant depreciation rate $\delta$ in equation (2) is replaced by $\tilde{\delta}_{t}=0.1311-\left(\pi_{t}-\bar{\pi}_{t}\right) / 100$, and the corresponding stock of knowledge is identified by $\tilde{M}_{k t}(k=i, j) 16$

As long time series are only available for the Ginarte-Park index, we do not consider EOS when $\tilde{M}$ is included in the regressions. The results are reported in Table 5 . Once again, we observe a dual effect of a more stringent protection of the intellectual property right on cooperative technological (patents) and scientific (publications) collaborations, confirming the results of our baseline regression (Table 4).

Next, following the recent theoretical prediction suggesting that firms strategically tend to adopt a disclosure regime based on the simultaneous use of patents and papers, i.e. patentpaper pairs, (Gans, Murray and Stern, 2017), we explore the possibility of cross-fertilization between patents and publications by including both measures of mass in the same regression. Relying on the distinctive differences between the patent and scientific publication system, with this alternative set of regressions we explore the issue of whether technological collaborations are related to the attractiveness in science (publications), and, vice versa, whether scientific collaborations are related to the technological capabilities of the country. Results are reported in Table 6, where $M P a t_{k t}$ and $M P u b_{k t}$ with $(k=i, j)$ identify the two measures of mass computed on the basis of, respectively, patent and publication 17 Again, results appear to be robust, displaying the same dual effect of IPR protection that we found in the main estimation.

\subsection{Additional control variables}

To allow for alternative determinants of technological and scientific collaborations in pharmaceuticals, we add control variables that reflect the state of the art of both basic and advanced research in each country. In particular, in order to control for domestic research intensity, we include the amount of R\&D expenditure as a fraction of GDP $(R D)$, and the number of researchers in R\&D per million people (Res). Moreover, we use the FDI inflow as a fraction of GDP $(F D I)$, and we simultaneously control for alternative measures of the "attraction force" of both countries.

As a second set of potentially relevant variables for research collaborations among countries, we explore the relevance of government expenditure in education as a fraction of GDP $(E d u)$, as well as the Economic Summary Index, reported by the Fraser Institute, as an indicator of the

\footnotetext{
${ }^{16}$ Notice that we have tried also different Ginarte-Park index cut-off, obtaining the same qualitative results.

${ }^{17}$ In the following sets of regression, we consider the depreciation rate of our baseline specification, i.e. $\delta=$ $13.11 \%$.
} 
Table 6: Estimation results including both measures of mass

\begin{tabular}{|c|c|c|c|c|c|c|}
\hline \multirow[b]{2}{*}{ IPR measure } & \multicolumn{2}{|c|}{$\begin{array}{c}\text { Patents } \\
\text { (applicants) }\end{array}$} & \multicolumn{2}{|c|}{$\begin{array}{c}\text { Patents } \\
\text { (inventors) }\end{array}$} & \multicolumn{2}{|c|}{ Publications } \\
\hline & $G-P$ & $E O S$ & $G-P$ & $E O S$ & $G-P$ & $E O S$ \\
\hline$\overline{l n}$ MPat $t_{i t-1}$ & $\begin{array}{l}0.244 \\
(0.306)\end{array}$ & $\begin{array}{l}-0.037 \\
(0.214)\end{array}$ & $\begin{array}{l}1.589^{* *} \\
(0.680)\end{array}$ & $\begin{array}{l}1.146^{* *} \\
(0.528)\end{array}$ & $\begin{array}{l}-0.051 \\
(0.049)\end{array}$ & $\begin{array}{l}-0.038 \\
(0.072)\end{array}$ \\
\hline $\ln M P a t_{j t-1}$ & $\begin{array}{l}0.782^{*} \\
(0.431)\end{array}$ & $\begin{array}{l}0.459^{* *} \\
(0.190)\end{array}$ & $\begin{array}{l}1.008^{* * *} \\
(0.067)\end{array}$ & $\begin{array}{l}0.689^{* * *} \\
(0.087)\end{array}$ & $\begin{array}{l}0.068 \\
(0.059)\end{array}$ & $\begin{array}{l}0.015 \\
(0.051)\end{array}$ \\
\hline $\ln M P u b_{i t-1}$ & $\begin{array}{l}1.021^{*} \\
(0.602)\end{array}$ & $\begin{array}{l}0.341 \\
(0.330)\end{array}$ & $\begin{array}{l}-0.481 \\
(0.719)\end{array}$ & $\begin{array}{l}-0.182 \\
(0.449)\end{array}$ & $\begin{array}{l}0.297^{* *} \\
(0.119)\end{array}$ & $\begin{array}{l}0.261^{* *} \\
(0.104)\end{array}$ \\
\hline $\ln M P u b_{j t-1}$ & $\begin{array}{l}0.561 \\
(0.505)\end{array}$ & $\begin{array}{l}1.199^{* * *} \\
(0.284)\end{array}$ & $\begin{array}{l}-0.356 \\
(0.241)\end{array}$ & $\begin{array}{l}0.435 \\
(0.364)\end{array}$ & $\begin{array}{l}0.487^{* * *} \\
(0.139)\end{array}$ & $\begin{array}{l}0.613^{* * *} \\
(0.162)\end{array}$ \\
\hline $\ln I P R_{i t}$ & $\begin{array}{l}-31.880^{* * *} \\
(11.166)\end{array}$ & $\begin{array}{l}2.275^{* *} \\
(1.039)\end{array}$ & $\begin{array}{l}7.127 \\
(5.215)\end{array}$ & $\begin{array}{l}0.739^{*} \\
(0.435)\end{array}$ & $\begin{array}{l}-2.636^{* * *} \\
(0.800)\end{array}$ & $\begin{array}{l}-0.171 \\
(0.363)\end{array}$ \\
\hline $\ln I P R_{j t}$ & $\begin{array}{l}-3.621^{* *} \\
(1.428)\end{array}$ & $\begin{array}{l}0.277 \\
(0.616)\end{array}$ & $\begin{array}{l}-2.379^{* * *} \\
(0.804)\end{array}$ & $\begin{array}{l}-0.399 \\
(0.446)\end{array}$ & $\begin{array}{l}1.202^{* * *} \\
(0.187)\end{array}$ & $\begin{array}{c}0.357^{* *} \\
(0.149)\end{array}$ \\
\hline $\bar{C}_{i j P}$ & $\begin{array}{l}1.477^{* * *} \\
(0.309)\end{array}$ & $\begin{array}{l}1.350^{* * *} \\
(0.337)\end{array}$ & $\begin{array}{l}-0.106 \\
(0.354)\end{array}$ & $\begin{array}{l}0.397 \\
(0.274)\end{array}$ & $\begin{array}{l}0.952^{* * *} \\
(0.042)\end{array}$ & $\begin{array}{l}0.877^{* * *} \\
(0.085)\end{array}$ \\
\hline Constant & $\begin{array}{l}30.925^{* *} \\
(12.399)\end{array}$ & $\begin{array}{l}-20.784^{* * *} \\
\text { (2.002) }\end{array}$ & $\begin{array}{l}-16.941^{* *} \\
(7.842)\end{array}$ & $\begin{array}{l}-14.876^{* * *} \\
(3.011)\end{array}$ & $\begin{array}{l}-3.893^{* * *} \\
(0.488)\end{array}$ & $\begin{array}{l}-6.871^{* * *} \\
(2.377)\end{array}$ \\
\hline N. obs. & 238 & 1071 & 238 & 1071 & 238 & 1071 \\
\hline
\end{tabular}

Note: Statistical significance at ${ }^{* *} 1 \%,{ }^{* *} 5 \%,{ }^{*} 10 \%$.

overall business climate in a given country $(B C) .18$

Furthermore, we acknowledge that the specific historical period of our sample is characterized by a considerable diffusion of the Internet (within our panel of countries, the average number of users per 100 people increased from 24.37 in 2000 to 66.06 in 2010). Hence, given the Internet's dominant role in communication, especially after the introduction of software which allows more easily video conference calls (e.g. Skype), we include the log-number of Internet users per 100 residents $\left(\right.$ Int $_{k t}$ with $\left.k=i, j\right)$ to control for its influence in facilitating overseas cooperation.19

Finally, in order to control for the commercial proximity within the pharmaceutical sector between the two countries that are part of the bilateral research cooperation, the sum of this sector imports and exports is considered (as percentage of GDP, Trade) ${ }^{20}$ We report in Table 7 and Table 8 the analysis on technological collaborations, and in Table 9 and in Table 10 the analysis on scientific collaborations. To save space, in the case of patents only counts on the

\footnotetext{
${ }^{18}$ For complete details see http://www.freetheworld.com/.

${ }^{19}$ The variables $R D_{k t}, R e s_{k t}, E d u_{k t}, F D I_{k t}$, and $I n t_{k t}$ where $k=i, j$ have been extracted from the World Bank statistics, see http://data.worldbank.org/indicator. Notice that these variables refer to the overall economy and are not limited to the pharmaceutical industry.

${ }^{20}$ Trade data in pharmaceuticals have been extracted from the OECD, Bilateral Trade in Goods by Industry and End-use.
} 
Table 7: Estimation results for patents using additional control variables and EOS index

\begin{tabular}{|c|c|c|c|c|c|c|c|}
\hline \multirow[b]{2}{*}{$I P R$ measure } & \multicolumn{7}{|c|}{ Patents (applicants) } \\
\hline & $E O S$ & $E O S$ & $E O S$ & $E O S$ & $E O S$ & $E O S$ & $E O S$ \\
\hline \multirow[t]{2}{*}{$\ln M_{i t-1}$} & $0.471^{* * *}$ & $0.451^{* *}$ & 0.161 & 0.140 & 0.277 & 0.329 & $0.700^{* * *}$ \\
\hline & $(0.143)$ & $(0.178)$ & (0.219) & $(0.169)$ & (0.197) & $(0.234)$ & (0.192) \\
\hline \multirow[t]{2}{*}{$\ln M_{j t-1}$} & $0.926^{* * *}$ & $0.734^{* * *}$ & $1.170^{* * *}$ & $1.006^{* *}$ & $0.818^{* * *}$ & $0.452^{* * *}$ & $1.092^{* * *}$ \\
\hline & $(0.215)$ & $(0.164)$ & (0.372) & $(0.485)$ & $(0.178)$ & $(0.070)$ & $(0.348)$ \\
\hline \multirow[t]{2}{*}{$\ln I P R_{i t}$} & $3.411^{* * *}$ & $1.718^{* *}$ & $2.615^{*}$ & 1.199 & 0.969 & 0.584 & 0.188 \\
\hline & $(1.160)$ & $(0.842)$ & $(1.448)$ & $(0.961)$ & (1.141) & (0.909) & $(1.088)$ \\
\hline \multirow[t]{2}{*}{$\ln I P R_{j t}$} & 0.395 & $-0.430^{* *}$ & -0.425 & 0.201 & -0.284 & $0.713^{* * *}$ & -0.609 \\
\hline & $(0.358)$ & $(0.179)$ & (0.652) & $(0.898)$ & $(0.815)$ & $(0.180)$ & $(0.791)$ \\
\hline \multirow[t]{2}{*}{$\ln R D_{i t}$} & $-1.963^{* * *}$ & & & & & & \\
\hline & $(0.721)$ & & & & & & \\
\hline \multirow[t]{2}{*}{$\ln R D_{j t}$} & $-1.058^{* * *}$ & & & & & & \\
\hline & $(0.326)$ & & & & & & \\
\hline \multirow[t]{2}{*}{$\ln R e s_{i t}$} & & -0.367 & & & & & \\
\hline & & $(0.361)$ & & & & & \\
\hline \multirow[t]{2}{*}{$\ln R e s_{j t}$} & & $-0.501^{* * *}$ & & & & & \\
\hline & & $(0.095)$ & & & & & \\
\hline \multirow[t]{2}{*}{$\ln E d u_{i t}$} & & & -1.158 & & & & \\
\hline & & & $(0.950)$ & & & & \\
\hline \multirow[t]{2}{*}{$\ln E d u_{j t}$} & & & 0.121 & & & & \\
\hline & & & $(1.461)$ & & & & \\
\hline \multirow[t]{2}{*}{$\ln B C_{i t}$} & & & & $4.987^{* * *}$ & & & \\
\hline & & & & (1.781) & & & \\
\hline \multirow[t]{2}{*}{$\ln B C_{j t}$} & & & & -2.581 & & & \\
\hline & & & & $(4.297)$ & & & \\
\hline \multirow[t]{2}{*}{$\ln F D I_{i t}$} & & & & & $0.375^{* *}$ & & \\
\hline & & & & & $(0.178)$ & & \\
\hline \multirow[t]{2}{*}{$\ln F D I_{j t}$} & & & & & -0.123 & & \\
\hline & & & & & $(0.316)$ & & \\
\hline \multirow[t]{2}{*}{$\ln I n t_{i t}$} & & & & & & $0.770^{* * *}$ & \\
\hline & & & & & & $(0.114)$ & \\
\hline \multirow[t]{2}{*}{$\ln I n t_{j t}$} & & & & & & $-0.532^{* * *}$ & \\
\hline & & & & & & $(0.144)$ & \\
\hline \multirow[t]{2}{*}{$\ln$ Trade $_{i j t}$} & & & & & & & $1.475^{* *}$ \\
\hline & & & & & & & $(0.641)$ \\
\hline \multirow{2}{*}{$\bar{C}_{i j P}$} & $1.045^{* * *}$ & $1.044^{* * *}$ & $1.318^{* * *}$ & $1.195^{* * *}$ & $1.326^{* * *}$ & $0.970^{* * *}$ & $1.663^{* * *}$ \\
\hline & $(0.231)$ & $(0.213)$ & $(0.409)$ & $(0.301)$ & $(0.340)$ & (0.272) & $(0.521)$ \\
\hline \multirow[t]{2}{*}{ Constant } & $-14.264^{* * *}$ & -3.929 & $-9.449^{* *}$ & -14.508 & $-8.379^{* * *}$ & $-8.806^{* * *}$ & 16.921 \\
\hline & $(2.245)$ & (2.923) & $(4.684)$ & (11.630) & (2.864) & (1.999) & $(11.769)$ \\
\hline N. obs. & 994 & 851 & 638 & 1071 & 1029 & 1071 & 1040 \\
\hline
\end{tabular}

Note: In parenthesis we report standard errors. Statistical significance at ${ }^{* * *} 1 \%,{ }^{* *} 5 \%,{ }^{*} 10 \%$. 
Table 8: Estimation results for patents using additional control variables and G-P index

\begin{tabular}{|c|c|c|c|c|c|c|c|}
\hline \multirow[b]{2}{*}{ IPR measure } & \multicolumn{7}{|c|}{ Patents (applicants) } \\
\hline & $G-P$ & $G-P$ & $G-P$ & $G-P$ & $G-P$ & $G-P$ & $G-P$ \\
\hline \multirow[t]{2}{*}{$\ln M_{i t-1}$} & $0.914^{* * *}$ & $0.701^{* * *}$ & $1.508^{* * *}$ & $0.599^{* * *}$ & $0.759^{* * *}$ & $0.748^{* * *}$ & $0.890^{* * *}$ \\
\hline & (0.239) & $(0.181)$ & $(0.324)$ & $(0.146)$ & $(0.151)$ & $(0.154)$ & (0.172) \\
\hline \multirow[t]{2}{*}{$\ln M_{j t-1}$} & $0.966^{* * *}$ & $0.793^{* * *}$ & $1.196^{* * *}$ & $1.132^{* * *}$ & $0.958^{* * *}$ & $0.793^{* * *}$ & $1.099^{* *}$ \\
\hline & (0.213) & (0.235) & (0.162) & $(0.336)$ & $(0.210)$ & $(0.396)$ & (0.305) \\
\hline \multirow[t]{2}{*}{$\ln I P R_{i t}$} & $-29.429^{* *}$ & $-32.907^{* *}$ & $-44.526^{* * *}$ & $-25.369^{* * *}$ & $-26.836^{* * *}$ & $-28.267^{* *}$ & $-17.155^{* *}$ \\
\hline & (11.930) & (12.870) & (8.244) & (9.690) & $(9.470)$ & $(12.040)$ & $(7.469)$ \\
\hline \multirow[t]{2}{*}{$\ln I P R_{j t}$} & $-3.210^{* * *}$ & $-2.520^{* * *}$ & $-6.049^{* * *}$ & $-4.185^{* *}$ & $-3.943^{* * *}$ & $-2.278^{* *}$ & $-3.714^{* * *}$ \\
\hline & $(0.801)$ & $(0.778)$ & (0.982) & $(0.775)$ & $(0.483)$ & (1.318) & $(0.967)$ \\
\hline \multirow[t]{2}{*}{$\ln R D_{i t}$} & -0.890 & & & & & & \\
\hline & $(0.708)$ & & & & & & \\
\hline \multirow[t]{2}{*}{$\ln R D_{j t}$} & $-0.518^{* *}$ & & & & & & \\
\hline & (0.210) & & & & & & \\
\hline \multirow[t]{2}{*}{$\ln R e s_{i t}$} & & 0.595 & & & & & \\
\hline & & $(0.497)$ & & & & & \\
\hline \multirow[t]{2}{*}{$\ln R e s_{j t}$} & & -0.203 & & & & & \\
\hline & & $(0.145)$ & & & & & \\
\hline \multirow[t]{2}{*}{$\ln E d u_{i t}$} & & & 0.684 & & & & \\
\hline & & & (1.237) & & & & \\
\hline \multirow[t]{2}{*}{$\ln E d u_{j t}$} & & & 0.141 & & & & \\
\hline & & & $(0.949)$ & & & & \\
\hline \multirow[t]{2}{*}{$\ln B C_{i t}$} & & & & 4.817 & & & \\
\hline & & & & (3.000) & & & \\
\hline \multirow[t]{2}{*}{$\ln B C_{j t}$} & & & & -0.369 & & & \\
\hline & & & & (0.921) & & & \\
\hline \multirow[t]{2}{*}{$\ln F D I_{i t}$} & & & & & 0.148 & & \\
\hline & & & & & $(0.206)$ & & \\
\hline \multirow[t]{2}{*}{$\ln F D I_{j t}$} & & & & & 0.005 & & \\
\hline & & & & & (0.243) & & \\
\hline \multirow[t]{2}{*}{$\ln I n t_{i t}$} & & & & & & 0.295 & \\
\hline & & & & & & $(0.365)$ & \\
\hline \multirow[t]{2}{*}{$\ln I n t_{j t}$} & & & & & & $-0.218^{*}$ & \\
\hline & & & & & & $(0.130)$ & \\
\hline \multirow[t]{2}{*}{$\ln \operatorname{Trade}_{i j t}$} & & & & & & & $1.072^{* * *}$ \\
\hline & & & & & & & $(0.236)$ \\
\hline \multirow[t]{2}{*}{$\bar{C}_{i j P}$} & $1.527^{* * *}$ & $1.771^{* * *}$ & $1.305^{* * *}$ & $1.566^{* * *}$ & $1.630^{* * *}$ & $1.602^{* * *}$ & $1.794^{* * *}$ \\
\hline & $(0.437)$ & $(0.526)$ & $(0.418)$ & (0.390) & $(0.377)$ & $(0.418)$ & $(0.571)$ \\
\hline \multirow[t]{2}{*}{ Constant } & $36.796^{* *}$ & $39.624^{* *}$ & $55.262^{* * *}$ & 23.036 & $33.870^{* *}$ & $35.063^{* *}$ & $37.347^{* * *}$ \\
\hline & (16.934) & (18.733) & $(7.796)$ & (14.832) & (13.310) & $(17.417)$ & $(14.040)$ \\
\hline N. obs. & 210 & 203 & 145 & 238 & 238 & 238 & 230 \\
\hline
\end{tabular}

Note: In parenthesis we report standard errors. Statistical significance at ${ }^{* * *} 1 \%,{ }^{* *} 5 \%,{ }^{*} 10 \%$. 
Table 9: Estimation results for publications using additional control variables and EOS index

\begin{tabular}{|c|c|c|c|c|c|c|c|}
\hline \multirow[b]{2}{*}{ IPR measure } & \multicolumn{7}{|c|}{ Publications } \\
\hline & $E O S$ & $E O S$ & $E O S$ & $E O S$ & $E O S$ & $E O S$ & $E O S$ \\
\hline \multirow{2}{*}{$\ln M_{i t-1}$} & $0.214^{* * *}$ & $0.238^{* * *}$ & $0.318^{* * *}$ & $0.232^{* * *}$ & $0.281^{* * *}$ & $0.242^{* * *}$ & $0.252^{* * *}$ \\
\hline & $(0.047)$ & $(0.065)$ & $(0.076)$ & (0.083) & $(0.036)$ & (0.030) & $(0.065)$ \\
\hline \multirow[t]{2}{*}{$\ln M_{j t-1}$} & $0.649^{* * *}$ & $0.716^{* * *}$ & $0.422^{* * *}$ & $0.697^{* * *}$ & $0.663^{* * *}$ & $0.778^{* * *}$ & $0.713^{* * *}$ \\
\hline & $(0.135)$ & $(0.124)$ & $(0.049)$ & $(0.094)$ & $(0.075)$ & $(0.166)$ & $(0.169)$ \\
\hline \multirow[t]{2}{*}{$\ln I P R_{i t}$} & -0.253 & -0.453 & $-0.708^{* *}$ & $-0.562^{* * *}$ & -0.285 & .238 & -0.361 \\
\hline & $(0.509)$ & $(0.501)$ & (0.279) & (0.201) & (0.293) & (0.412) & $(0.495)$ \\
\hline \multirow{2}{*}{$\ln I P R_{j t}$} & 0.306 & $0.503^{* * *}$ & $0.493^{* * *}$ & $0.514^{*}$ & $0.542^{* *}$ & $0.370^{* *}$ & $0.446^{* * *}$ \\
\hline & $(0.216)$ & $(0.153)$ & (0.133) & $(0.274)$ & $(0.199)$ & $(0.184)$ & $(0.158)$ \\
\hline \multirow[t]{2}{*}{$\ln R D_{i t}$} & -0.104 & & & & & & \\
\hline & $(0.141)$ & & & & & & \\
\hline \multirow[t]{2}{*}{$\ln R D_{j t}$} & 0.188 & & & & & & \\
\hline & (0.134) & & & & & & \\
\hline \multirow[t]{2}{*}{$\ln R e s_{i t}$} & & 0.061 & & & & & \\
\hline & & (0.090) & & & & & \\
\hline \multirow[t]{2}{*}{$\ln R e s_{j t}$} & & 0.044 & & & & & \\
\hline & & $(0.054)$ & & & & & \\
\hline \multirow[t]{2}{*}{$\ln E d u_{i t}$} & & & 0.020 & & & & \\
\hline & & & $(0.161)$ & & & & \\
\hline \multirow[t]{2}{*}{$\ln E d u_{j t}$} & & & $0.319^{*}$ & & & & \\
\hline & & & $(0.178)$ & & & & \\
\hline \multirow[t]{2}{*}{$\ln B C_{i t}$} & & & & 1.114 & & & \\
\hline & & & & (0.970) & & & \\
\hline \multirow[t]{2}{*}{$\ln B C_{j t}$} & & & & -0.531 & & & \\
\hline & & & & $(1.234)$ & & & \\
\hline \multirow[t]{2}{*}{$\ln F D I_{i t}$} & & & & & -0.033 & & \\
\hline & & & & & $(0.066)$ & & \\
\hline \multirow[t]{2}{*}{$\ln F D I_{j t}$} & & & & & 0.190 & & \\
\hline & & & & & (0.123) & & \\
\hline \multirow[t]{2}{*}{$\ln I n t_{i t}$} & & & & & & $-0.392^{* *}$ & \\
\hline & & & & & & $(0.190)$ & \\
\hline \multirow[t]{2}{*}{$\ln I n t_{j t}$} & & & & & & 0.085 & \\
\hline & & & & & & $(0.087)$ & \\
\hline \multirow[t]{2}{*}{$\ln$ Trade $_{i j t}$} & & & & & & & 0.063 \\
\hline & & & & & & & $(0.096)$ \\
\hline \multirow{2}{*}{$\bar{C}_{i j P}$} & $0.894^{* * *}$ & $0.850^{* * *}$ & $0.746^{* * *}$ & $0.843^{* * *}$ & $.804^{* * *}$ & $0.851^{* * *}$ & $0.878^{* * *}$ \\
\hline & $(0.088)$ & $(0.064)$ & $(0.061)$ & (0.091) & $(0.054)$ & $(0.054)$ & $(0.077)$ \\
\hline \multirow[t]{2}{*}{ Constant } & $-6.425^{* * *}$ & $-7.899^{* * *}$ & $-5.035^{* * *}$ & $-7.950^{* * *}$ & $-7.482^{* * *}$ & $-7.814^{* * *}$ & $-6.221^{* * *}$ \\
\hline & (2.236) & $(1.648)$ & (1.273) & $(1.567)$ & (1.702) & (1.722) & (0.8723) \\
\hline N. obs. & 1106 & 941 & 698 & 1190 & 1141 & 1190 & 1157 \\
\hline
\end{tabular}

Note: In parenthesis we report standard errors. Statistical significance at ${ }^{* * *} 1 \%,{ }^{* *} 5 \%,{ }^{*} 10 \%$. 
Table 10: Estimation results for publications using additional control variables and G-P index

\begin{tabular}{|c|c|c|c|c|c|c|c|}
\hline \multirow[b]{2}{*}{$I P R$ measure } & \multicolumn{7}{|c|}{ Publications } \\
\hline & $G-P$ & $G-P$ & $G-P$ & $G-P$ & $G-P$ & $G-P$ & $G-P$ \\
\hline \multirow[t]{2}{*}{$\ln M_{i t-1}$} & $0.197^{* * *}$ & $0.202^{* * *}$ & $0.209^{* *}$ & $0.194^{* * *}$ & $0.307^{* * *}$ & $0.225^{* * *}$ & $0.213^{* * *}$ \\
\hline & $(0.040)$ & $(0.044)$ & $(0.104)$ & $(0.066)$ & (0.099) & $(0.049)$ & $(0.069)$ \\
\hline \multirow[t]{2}{*}{$\ln M_{j t-1}$} & $0.474^{* * *}$ & $0.612^{* * *}$ & $0.491^{* * *}$ & $0.577^{* * *}$ & $0.534^{* * *}$ & $0.670^{* * *}$ & $0.617^{* * *}$ \\
\hline & $(0.170)$ & $(0.180)$ & $(0.156)$ & (0.220) & (0.182) & $(0.160)$ & $(0.187)$ \\
\hline \multirow[t]{2}{*}{$\ln I P R_{i t}$} & $-2.731^{* * *}$ & $-2.889^{* *}$ & -0.955 & $-2.242^{* * *}$ & $-1.941^{* *}$ & $-2.402^{* * *}$ & $-2.287^{* * *}$ \\
\hline & $(0.769)$ & (1.152) & $(1.247)$ & $(0.801)$ & $(0.818)$ & $(0.791)$ & $(0.785)$ \\
\hline \multirow[t]{2}{*}{$\ln I P R_{j t}$} & $0.884^{* * *}$ & $1.122^{* * *}$ & $1.707^{*}$ & $1.224^{* * *}$ & 0.693 & $1.258^{* * *}$ & $1.234^{* * *}$ \\
\hline & $(0.183)$ & (0.393) & $(0.910)$ & $(0.286)$ & $(0.679)$ & $(0.356)$ & $(0.269)$ \\
\hline \multirow[t]{2}{*}{$\ln R D_{i t}$} & $-0.152^{* * *}$ & & & & & & \\
\hline & $(0.030)$ & & & & & & \\
\hline \multirow{2}{*}{$\ln R D_{j t}$} & $0.263^{* * *}$ & & & & & & \\
\hline & $(0.087)$ & & & & & & \\
\hline \multirow[t]{2}{*}{$\ln \operatorname{Res}_{i t}$} & & -0.022 & & & & & \\
\hline & & $(0.074)$ & & & & & \\
\hline \multirow[t]{2}{*}{$\ln R e s_{j t}$} & & 0.035 & & & & & \\
\hline & & $(0.086)$ & & & & & \\
\hline \multirow[t]{2}{*}{$\ln E d u_{i t}$} & & & -0.087 & & & & \\
\hline & & & $(0.259)$ & & & & \\
\hline \multirow[t]{2}{*}{$\ln E d u_{j t}$} & & & 0.341 & & & & \\
\hline & & & (0.295) & & & & \\
\hline \multirow[t]{2}{*}{$\ln B C_{i t}$} & & & & 0.884 & & & \\
\hline & & & & $(0.891)$ & & & \\
\hline \multirow[t]{2}{*}{$\ln B C_{j t}$} & & & & -0.392 & & & \\
\hline & & & & (1.889) & & & \\
\hline \multirow[t]{2}{*}{$\ln F D I_{i t}$} & & & & & 0.010 & & \\
\hline & & & & & (0.030) & & \\
\hline \multirow[t]{2}{*}{$\ln F D I_{j t}$} & & & & & $0.301^{*}$ & & \\
\hline & & & & & $(0.174)$ & & \\
\hline \multirow[t]{2}{*}{$\ln I n t_{i t}$} & & & & & & $-0.199^{* *}$ & \\
\hline & & & & & & $(0.095)$ & \\
\hline \multirow[t]{2}{*}{$\ln I n t_{j t}$} & & & & & & 0.001 & \\
\hline & & & & & & $(0.096)$ & \\
\hline \multirow[t]{2}{*}{$\ln$ Trade $_{i j t}$} & & & & & & & 0.034 \\
\hline & & & & & & & $(0.069)$ \\
\hline \multirow[t]{2}{*}{$\bar{C}_{i j P}$} & $1.006^{* * *}$ & $0.986^{* * *}$ & $0.874^{* * *}$ & $0.956^{* * *}$ & $.855^{* * *}$ & $0.969^{* * *}$ & $0.979^{* * *}$ \\
\hline & $(0.053)$ & $(0.046)$ & $(0.087)$ & $(0.067)$ & $(0.054)$ & $(0.046)$ & $(0.046)$ \\
\hline \multirow[t]{2}{*}{ Constant } & $-2.317^{* * *}$ & $-3.719^{* * *}$ & $-6.563^{*}$ & -5.479 & $-4.900^{* * *}$ & $-4.568^{* * *}$ & $-4.212^{* * *}$ \\
\hline & (0.402) & $(0.687)$ & (3.388) & (3.644) & $(0.859)$ & $(0.455)$ & (0.362) \\
\hline N. obs. & 210 & 203 & 145 & 238 & 238 & 238 & 230 \\
\hline
\end{tabular}

Note: In parenthesis we report standard errors. Statistical significance at ${ }^{* * *} 1 \%,{ }^{* *} 5 \%,{ }^{*} 10 \%$. 
Table 11: Estimation results using various lags of patent protection indices

\begin{tabular}{|c|c|c|c|c|c|c|c|c|}
\hline \multirow[b]{2}{*}{$I P R$ measure } & \multicolumn{4}{|c|}{$\begin{array}{c}\text { Patents } \\
\text { (applicants) }\end{array}$} & \multicolumn{4}{|c|}{ Publications } \\
\hline & $G-P$ & $E O S$ & $E O S$ & $E O S$ & $G-P$ & $E O S$ & $E O S$ & $E O S$ \\
\hline \multirow[t]{2}{*}{$\ln M_{i t-1}$} & $0.816^{* * *}$ & 0.169 & 0.164 & 0.171 & $0.187^{* * *}$ & $0.213^{* * *}$ & $0.211^{\text {*** }}$ & $0.205^{* * *}$ \\
\hline & $(0.156)$ & $(0.187)$ & (0.193) & (0.192) & $(0.044)$ & $(0.044)$ & $(0.043)$ & (0.039) \\
\hline \multirow[t]{2}{*}{$\ln M_{j t-1}$} & $1.008^{* * *}$ & $1.044^{* * *}$ & $1.031^{* * *}$ & $1.026^{* * *}$ & $0.643^{* * *}$ & $0.689^{* * *}$ & $0.654^{* * *}$ & $0.683^{* * *}$ \\
\hline & $(0.196)$ & $(0.265)$ & $(0.280)$ & (0.288) & (0.189) & (0.201) & (0.199) & (0.194) \\
\hline \multirow[t]{2}{*}{$\ln I P R_{i t}$} & & & 1.072 & 0.136 & & & -0.191 & -0.269 \\
\hline & & & (0.723) & (0.683) & & & (0.252) & (0.221) \\
\hline \multirow[t]{2}{*}{$\ln I P R_{i t-1}$} & $-22.811^{* *}$ & $2.027^{* *}$ & $1.156^{* * *}$ & -0.125 & -0.867 & -0.260 & -0.078 & 0.071 \\
\hline & $(10.437)$ & $(0.901)$ & $(0.416)$ & $(0.668)$ & (0.903) & (0.263) & (0.090) & (0.110) \\
\hline \multirow[t]{2}{*}{$\ln I P R_{i t-2}$} & & & & $2.888^{* * *}$ & & & & -0.114 \\
\hline & & & & $(0.434)$ & & & & (0.104) \\
\hline \multirow[t]{2}{*}{$\ln I P R_{j t}$} & & & $0.701^{*}$ & $0.832^{* *}$ & & & $0.547^{*}$ & $0.504^{*}$ \\
\hline & & & $(0.417)$ & $(0.408)$ & & & (0.292) & (0.301) \\
\hline \multirow[t]{2}{*}{$\ln I P R_{j t-1}$} & $-3.969^{* * *}$ & -0.641 & $-1.207^{* *}$ & $-0.665^{*}$ & $1.271^{* * *}$ & $0.367^{* * *}$ & -0.164 & $0.165^{* * *}$ \\
\hline & (0.939) & (0.702) & $(0.519)$ & $(0.360)$ & $(0.169)$ & (0.138) & (0.242) & $(0.060)$ \\
\hline \multirow[t]{2}{*}{$\ln I P R_{j t-2}$} & & & & $-0.774^{* *}$ & & & & -0.334 \\
\hline & & & & $(0.364)$ & & & & (0.223) \\
\hline \multirow{2}{*}{$\bar{C}_{i j P}$} & $1.253^{* * *}$ & $1.292^{* * *}$ & $1.301^{* * *}$ & $1.252^{* * *}$ & $0.923^{* * *}$ & $0.874^{* * *}$ & $0.879^{* * *}$ & $0.887^{* * *}$ \\
\hline & $(0.447)$ & $(0.306)$ & $(0.337)$ & $(0.310)$ & $(0.049)$ & $(0.083)$ & (0.082) & $0 .(0.087)$ \\
\hline \multirow[t]{2}{*}{ Constant } & $27.004^{*}$ & $-10.440^{* * *}$ & $-11.048^{* * *}$ & $-12.787^{* * *}$ & $-6.871^{* * *}$ & $-7.070^{* * *}$ & $-6.811^{* * *}$ & $-6.807^{* * *}$ \\
\hline & $(15.040)$ & $(2.418)$ & (2.782) & (2.866) & $(0.552)$ & (2.127) & (2.117) & (2.177) \\
\hline N. obs. & 238 & 952 & 952 & 833 & 238 & 1190 & 952 & 833 \\
\hline
\end{tabular}

Note: Statistical significance at ${ }^{* * *} 1 \%,{ }^{* *} 5 \%,{ }^{*} 10 \%$.

basis of the location of applicants are taken into account ${ }^{21}$ As for scientific collaborations (publications), with few exceptions, the positive effect of stringent IPR in country $j$ is confirmed. Omitting some negligible cases (i.e. government expenditure on education, sum of pharmaceutical import and export, the role of Internet), the additional control variables included in the regressions are generally not statistically significant. This may not seem surprising considering that these variables refer to country-wide phenomena, and not exclusively to the pharmaceutical industry. As we would expect, commercial proximity between the two countries, as measured by the Trade variable, is significant only in the case of technological collaborations. This confirms indeed how patent collaborations are more frequent between countries that are close trade partners.

\subsection{Various lags of IPR protection indices}

As the development process for a new drug involves several stages, including the completion of complex clinical trials, the period from when the molecule is isolated to the time the drug

\footnotetext{
${ }^{21}$ Further regression results are available from the authors upon request.
} 
reaches the market can easily become very long (Henderson and Cockburn, 1996). Hence, in this section we experiment with various lags of the IPR protection indices with the aim to capture potential delays in the impact of introducing a more stringent protection. We report in Table 11 our results which shown to be consistent with those in our main estimation. We still obtain that the IPR protection exerts a negative impact on joint patents and a positive effect on joint publications.

Table 12: Placebo regressions on publications in the field of Economics

\begin{tabular}{|c|c|c|c|}
\hline \multirow[b]{2}{*}{ IPR measure } & \multicolumn{3}{|c|}{ Publications } \\
\hline & $E O S$ & $G-P$ & $G-P$ \\
\hline \multirow[t]{2}{*}{$\ln M_{i t-1}$} & -0.030 & -0.056 & \\
\hline & $(0.175)$ & $(0.267)$ & \\
\hline \multirow{2}{*}{$\ln M_{j t-1}$} & $0.411^{* *}$ & 0.511 & \\
\hline & $(0.199)$ & $(0.354)$ & \\
\hline \multirow{2}{*}{$\ln \tilde{M}_{i t-1}$} & & & -0.056 \\
\hline & & & (0.263) \\
\hline \multirow[t]{2}{*}{$\ln \tilde{M}_{j t-1}$} & & & 0.518 \\
\hline & & & $(0.357)$ \\
\hline \multirow[t]{2}{*}{$\ln I P R_{i t}$} & 1.100 & -12.624 & -12.609 \\
\hline & $(0.906)$ & $(9.264)$ & (9.321) \\
\hline \multirow[t]{2}{*}{$\ln I P R_{j t}$} & 0.072 & 1.080 & 1.060 \\
\hline & $(0.684)$ & $(1.843)$ & (1.828) \\
\hline \multirow[t]{2}{*}{$\bar{C}_{i j P}$} & $3.187^{* * *}$ & $4.878^{* * *}$ & $4.882^{* * *}$ \\
\hline & $(1.081)$ & $(1.887)$ & $(1.888)$ \\
\hline \multirow[t]{2}{*}{ Constant } & $-6.920^{* * *}$ & 12.529 & 12.500 \\
\hline & (1.923) & (15.220) & $(15.279)$ \\
\hline N. obs. & 1190 & 238 & 238 \\
\hline
\end{tabular}

\subsection{A placebo regression for publications}

As discussed in the introduction, our decision to focus on the pharmaceutical domain was mainly driven by the high relevance that the level of legal protection for intellectual property is expected to have for research investments in this specific sector. Nevertheless, we cannot exclude with certainty that a result similar to what we have obtained might emerge for other sectors, where IPR protection has in reality no actual influence at all, calling into question the validity of our identification strategy. One way to exclude the risk of a spurious effect is to run a placebo regression for a sector in which we expect a priori that no effect should be detected. For this reason, we perform the same estimation for the case of scientific publications in the field of economics. Obviously, no patenting is involved in economics research and so the level of IPR 
protection cannot influence the amount of collaborations. As Table 12 shows, we do not find any significant effect on economics publications across all three specifications that differ with respect to the definition of mass and type of IPR index. Thus, we conclude that we can be sufficiently confident on the validity of our model identification 22 Moreover, to further reduce concern about possible endogeneity bias, we make use of economics as an interesting falsification test.

\section{Concluding remarks}

Although it is beyond any doubt that the links between cooperative agreements and intellectual property rights have important dynamic effects, the question whether the normative changes introduced in the protection of the IPR have reached the expected results is still open to debate.

Our research has been motivated by the global IPR reform introduced in 1995, providing a unique opportunity to study the effects of strengthening IPR rules. We investigated whether the evolution in the international cooperation in the pharmaceutical research has changed in response to a clearer set of institutions designed to defend intellectual property at the world level. Making use of both a subjective and an objective measure of the level of protection of the intellectual property, we obtained that a better defined set of rules inhibits collaborative patent applications but encourages collaborative scientific publications. These results turned out to be very robust to different specifications, to the inclusion of a large set of different control variables, and also to a placebo regression that confirms the validity of our identification strategy.

These two apparently contradicting findings can be interpreted in light of the recent studies that stress the importance of a clearly defined legal system in promoting research collaboration. Once a solid legal background is in place, the protection offered by patents become less necessary at an early stage of the research development, while it is more fruitful to provide the researchers with a larger freedom to take full advantage of the international cooperation. This is particularly true in a science-based sector, like the pharmaceutical, where the combination patent-publication is the standard.

However, since the reform of the IPR system is very recent, it would be interesting in the future to consider a longer time span, along with a wider set of industries and countries, in order to let countries develop the institutions and capabilities aimed at fostering collaborations between the developed and the developing world. What emerges from our results is that there is an important ongoing evolution in the way international research collaborations are coordinated, in response to a transformation of the institutions that protect the intellectual property. The implications are that a correct assessment of the effectiveness of a certain legal reform needs to examine the consequences for the broader outcome of the research process, and especially the impact for the patent-publication synergy.

\footnotetext{
${ }^{22}$ We would like to thank Beata Javorcik for suggesting, among other things, this validation check.
} 


\section{Acknowledgments}

We are very grateful to Vincenzo De Lipsis, Simona Gamba, Beata Javorcik, Margaret Kyle, Diego Lubian, Eric Pentecost, Stefan Szymanski, Tommaso Valletti, and Frank Windmeijer for insightful suggestions and fruitful discussions, and to the Associate Editor for very helpful comments received. Advices from Valeria Gattai, Giuliano Masiero, and all seminar participants in Amsterdam, Bristol, Helsinki, Istanbul, Milan, Rome, Norwich and Seville are gratefully acknowledged. We would also like to thank Massimiliano Cialdi for helpful assistance with the data collection. All remaining errors are our own. An earlier version was circulated as "International Cooperation in Pharmaceutical Research", Working Paper no. 62, Department of Economics, University of Verona. 


\section{References}

Anderson, James E and Eric Van Wincoop. 2003. "Gravity with Gravitas: a Solution to the Border Puzzle." American Economic Review 93(1):170-192.

Baker, Scott and Claudio Mezzetti. 2005. "Disclosure as a Strategy in the Patent Race." The Journal of Law and Economics 48(1):173-194.

Bessen, James and Eric Maskin. 2009. "Sequential Innovation, Patents, and Imitation." The RAND Journal of Economics 40(4):611-635.

Blundell, Richard, Rachel Griffith and Frank Windmeijer. 2002. "Individual Effects and Dynamics in Count Data Models." Journal of Econometrics 108(1):113-131.

Blundell, Richard, Rachel Griffith and John Van Reenen. 1995. "Dynamic Count Data Models of Technological Innovation." The Economic Journal pp. 333-344.

Branstetter, Lee, Ray Fisman, C Fritz Foley and Kamal Saggi. 2011. "Does Intellectual Property Rights Reform Spur Industrial Development?" Journal of International Economics 83(1):2736.

Cameron, A Colin, Jonah B Gelbach and Douglas L Miller. 2011. "Robust Inference with Multiway Clustering." Journal of Business \& Economic Statistics 29(2):238-249.

Chengsi, Zheng. 1998. "The TRIPS Agreement and Intellectual Property Protection in China." Duke Journal of Comparative \& International Law 9:219-227.

Cockburn, Iain M, Jean O Lanjouw and Mark Schankerman. 2016. "Patents and the global diffusion of new drugs." American Economic Review 106(1):136-64.

Cockburn, Iain M and Rebecca M Henderson. 1998. "Absorptive Capacity, Coauthoring Behavior, and the Organization of Research in Drug Discovery." The Journal of Industrial Economics 46(2):157-182.

Cockburn, Iain M and Rebecca M Henderson. 2000. "Publicly Funded Science and the Productivity of the Pharmaceutical Industry." Innovation Policy and the Economy 1:1-34.

Cohen, Wesley M, Richard R Nelson and John P Walsh. 2000. Protecting their Intellectual Assets: Appropriability Conditions and why US Manufacturing Firms Patent (or not). Technical report National Bureau of Economic Research.

Czarnitzki, Dirk, Katrin Hussinger and Cédric Schneider. 2015. "R\&D Collaboration with Uncertain Intellectual Property Rights." Review of Industrial Organization 46(2):183-204.

DiMasi, Joseph A, Henry G Grabowski and John Vernon. 2004. "R\&D Costs and Returns by Therapeutic Category." Drug Information Journal 38(3):211-223.

Ductor, Lorenzo. 2015. "Does Co-authorship Lead to Higher Academic Productivity?" Oxford Bulletin of Economics and Statistics 77(3):385-407. 
Erstling, Jay A and Ryan E Strom. 2009. "Korea's Patent Policy and Its Impact on Economic Development: A Model for Emerging Countries." San Diego International Law Journal 11:441-480.

Falvey, Rod, Neil Foster and David Greenaway. 2006. "Intellectual property rights and economic growth." Review of Development Economics 10(4):700-719.

Galtsova, Polina. 2008. "Intellectual Property Reform in Russia: Analysis of part four of the Russian Civil Code." Lund University, Sweden .

Gans, Joshua S, Fiona E Murray and Scott Stern. 2017. "Contracting Over the Disclosure of Scientific Knowledge: Intellectual Property and Academic Publication." Research Policy $46(4): 820-835$.

Ginarte, Juan C and Walter G Park. 1997. "Determinants of Patent Rights: A Cross-National Study." Research Policy 26(3):283-301.

Griliches, Zvi. 1990. "Patent Statistics as Economic Indicators: A Survey." Journal of Economic Literature 28(4):1661-1707.

Gwartney, James, Robert Lawson and Seth Norton. 2008. Economic Freedom of the World 2008 Annual Report. The Fraser Institute.

Hamdan-Livramento, Intan Maizurah. 2009. "Examining how TRIPS implementation affects access to foreign technologies for developing countries." CEMI, Working Paper 2009-001 .

Heller, Michael A and Rebecca S Eisenberg. 1998. "Can Patents Deter Innovation? The Anticommons in Biomedical Research." Science 280(5364):698-701.

Henderson, Rebecca and Iain M Cockburn. 1996. "Scale, Scope, and Spillovers: the Determinants of Research Productivity in Drug Discovery." The Rand Journal of Economics 27(1):3259.

IPO. 2017. "Intellectual Property Rights in India." https://assets.publishing. service.gov.uk/government/uploads/5\system/uploads/attachment_data/file/627956/ IP-Rights-in-India.pdf.

Kanwar, Sunil. 2012. "Intellectual Property Protection and Technology Licensing: the case of Developing Countries." The Journal of Law and Economics 55(3):539-564.

Katsoutacos, Yannis and David Ulph. 1998. "Endogenous spillovers and the performance of research joint ventures." The Journal of Industrial Economics 46(3):333-357.

Katz, Michael L. 1986. "An analysis of cooperative research and development." The RAND Journal of Economics 17(4):527-543.

Kyle, Margaret K and Anita M McGahan. 2012. "Investments in pharmaceuticals before and after TRIPS." Review of Economics and Statistics 94(4):1157-1172. 
Kyle, Margaret and Yi Qian. 2014. Intellectual Property Rights and Access to Innovation: Evidence from TRIPS. Technical report National Bureau of Economic Research.

Lach, Saul and Mark Schankerman. 2008. "Incentives and Invention in Universities." The RAND Journal of Economics 39(2):403-433.

Lin, Ping and Wen Zhou. 2013. "The effects of competition on the R\&D portfolios of multiproduct firms." International Journal of Industrial Organization 31(1):83-91.

Liu, Wen-Hsien. 2016. "Intellectual Property Rights, FDI, R\&D and Economic Growth: A Cross-country Empirical Analysis." The World Economy 39(7):983-1004.

Maskus, Keith E and Mohan Penubarti. 2012. "Trade-related intellectual property rights." The Oxford Handbook on The World Trade Organization p. 394.

Merges, Robert P and Richard R Nelson. 1990. "On the Complex Economics of Patent Scope." Columbia Law Review 90(4):839-916.

Murray, Fiona and Scott Stern. 2007. "Do Formal Intellectual Property Rights Hinder the Free Flow of Scientific Knowledge?: An Empirical Test of the Anti-Commons Hypothesis." Journal of Economic Behavior \& Organization 63(4):648-687.

Park, Gwangman and Yongtae Park. 2006. "On the Measurement of Patent Stock as Knowledge Indicators." Technological Forecasting and Social Change 73(7):793-812.

Park, Walter G. 2008. "International Patent Protection: 1960-2005." Research Policy 37(4):761766.

Picci, Lucio. 2010. "The Internationalization of Inventive Activity: A gravity Model Using Patent Data." Research Policy 39(8):1070-1081.

Ponce, Carlos J. 2008. "More secrecy... more knowledge disclosure? On disclosure outside of patents." European University Institute .

Qian, Yi. 2007. "Do National Patent Laws Stimulate Domestic Innovation in a Global Patenting Environment? A Cross-Country Analysis of Pharmaceutical Patent Protection, 1978-2002." The Review of Economics and Statistics 89(3):436-453.

Sandoval, Rodolpho and Chung-Pok Leung. 1993. "A Comparative Analysis of Intellectual Property Law in the United States and Mexico, and the Free Trade Agreement." Maryland Journal of International Law and Trade 17:145.

Schulz, Claudia and Mark Wu. 2004. The TRIPS Agreement and Intellectual Property Protection in Brazil. In Proceedings of the Annual Meeting (American Society of International Law). JSTOR pp. 100-106.

Scotchmer, Suzanne. 1991. "Standing on the Shoulders of Giants: Cumulative Research and the Patent Law." Journal of Economic Perspectives 5(1):29-41. 
Shin, Wonkyu, Keun Lee and Walter G Park. 2016. "When an Importer's Protection of IPR Interacts with an Exporter's Level of Technology: Comparing the Impacts on the Exports of the North and South." The World Economy 39(6):772-802.

Silva, JMC Santos and Silvana Tenreyro. 2006. "The Log of Gravity." The Review of Economics and Statistics 88(4):641-658.

Silva, JMC Santos and Silvana Tenreyro. 2011. "Further Simulation Evidence on the Performance of the Poisson Pseudo-Maximum Likelihood Estimator." Economics Letters 112(2):220-222.

Stokes, Donald E. 1997. Pasteur's Quadrant. Brookings Institution Press.

Suluk, Cahit. 2018. "Basics of the New Turkish Industrial Property Law." Journal of Intellectual Property Law \& Practice 13:492-503.

Windmeijer, Frank. 2008. GMM for Panel Data Count Models. in The Econometrics of Panel Data eds. Matyas, Laszlo and Sevestre, Patrick Springer Berlin Heidelberg pp. 603-624.

WTO. 2016. "World Trade Organization Annual Report." https://www.wto.org/english/res_ e/booksp_e/anrep_e/anrep16_e.pdf. 